Bożena Ostrowska ${ }^{1}$, Karolina Szostek ${ }^{1}$, Małgorzata Marcysiak ${ }^{1}$

1 Wydział Ochrony Zdrowia i Nauk Humanistycznych, Państwowa Wyższa Szkoła Zawodowa w Ciechanowie

\title{
Postawy życiowe studentów pielęgniarstwa a ich stosunek do aborcji
}

\author{
Life Attitudes of Nursing Students and their Attitudes towards Abortion
}

\section{Streszczenie}

Wstęp. Problem aborcji, podobnie jak eutanazji oraz innych kontrowersyjnych dylematów etycznych naszych czasów, dzieli społeczeństwo niemal całego świata na jego zwolenników i przeciwników. Zadowalającego rozwiązania dla jednych, jak i dla drugich zapewne nigdy nikt nie znajdzie, ale nie zwalnia to ludzi od dyskusji i poszukiwania najlepszego w danym czasie rozwiązania.

Cel. Celem badań było poznanie postaw życiowych studentów pielęgniarstwa i ich wpływu na stosunek studentów do aborcji.

Materiał i metody. W celu uzyskania materiału badawczego zastosowano metodę sondażu diagnostycznego, techniką było ankietowanie, zaś narzędziem autorski kwestionariusz ankiety. Do badania wykorzystano również standaryzowany kwestionariusz postaw życiowych, który składał się z 10 stwierdzeń. Badania przeprowadzono wśród 80 studentów kierunku pielęgniarstwa oraz 80 studentów kierunku ekonomii Państwowej Wyższej Szkoły Zawodowej w Ciechanowie. Ankietowanych scharakteryzowano pod względem płci, wieku, miejsca zamieszkania i aktywności religijnej.

Wyniki. Analiza materiału badawczego wykazała, że postawy życiowe studentów pielęgniarstwa i ekonomii częściowo wpływają na ich stosunek do aborcji. Z ogólnej liczby badanych studentów - 53\% była przeciwnikami aborcji. Podobna liczba badanych miała neutralny stosunek do przerywania ciąży, natomiast ponad połowa - 55\% nie opowiadała się za legalizacją aborcji w Polsce. Ponad połowa badanych studentów pielęgniarstwa i ekonomii - 61,2\% uznała, że aborcja jest zabójstwem dokonanym na nienarodzonym dziecku, stwierdzeniu temu sprzeciwiło się - 13,1\% badanych. Ze stwierdzeniem, iż życie rozpoczyna się w momencie poczęcia zgodziło się - $67 \%$ badanych, natomiast przeciwne zdanie miało tylko 10,4\% badanych. Większość studentów - 67,5\% uważa że zabieg przerwania ciąży jest pozbawieniem dziecka praw do życia.

W zdecydowanej większości - 70,6\% badani uważali, że aborcja powinna być dopuszczalna, gdy stanowi zagrożenie dla zdrowia lub życia matki/dziecka. Aż $66 \%$ badanych studentów uważa, że zabieg przerywania ciąży powinien być dopuszczalny w momencie, gdy istnieje ryzyko ciężkiego upośledzeni płodu lub nieuleczalnej choroby. Jednocześnie wyrażają oni swoje poparcie w 59,4\% dla dopuszczalności aborcji w sytuacji, gdy powstała ona w wyniku czynu zabronionego. Osoby, które zadeklarowały swoją wiarę w 58,4\% nie opowiadały się za legalizacją aborcji w Polsce, natomiast 9,1\% osób nie deklarujących swojej wiary również wyraża taki stosunek. Ponad połowa studentów niewierzących - 63,7\% opowiada się za legalizacją aborcji, natomiast $23,5 \%$ respondentów wierzących również prezentuje taką opinię. Kobiety częściej odnoszą się negatywnie do poparcia oraz legalizacji aborcji w Polsce niż mężczyźni. 


\section{Wnioski.}

1. Istnieje rozbieżność pomiędzy deklarowanym światopoglądem a zachowaniem w zakresie dopuszczalności przerywania ciąży w różnych sytuacjach.

2. Deklarowane poparcie dla aborcji w znacznym stopniu uzależnione jest od konkretnej, opisywanej sytuacji.

3. Religia pełni istotną funkcję jako wyznacznik praw moralnych i społecznych i przekłada się na deklarowane poglądy na temat problemów bioetycznych.

4. Istnieje konieczność zwrócenia szczególnej uwagi na zagadnienia bioetyczne kształceniu studentów pielęgniarstwa.

5. Należy podjąć działania mające na celu uświadamianie młodych mężczyzn konsekwencji i skutków aborcji dla kobiety poprzez kampanie społeczne.

6. W kontynuacji badań warto uwzględnić szerszy zakres postaw życiowych niż tylko poczucie celowości.

\section{Abstract:}

Introduction. The problem of abortion, as well as other controversial issues such as euthanasia and other ethical dilemmas of our times, divide the society of nearly the whole world into both the supporters or opponents. Any satisfactory solution will probably never be found but this does not absolve people from debating and searching for the best possible solution to be found in respective time.

Aim. This study has aimed to investigate life attitudes of nursing students and influence of these attitudes upon the students' stance on abortion.

Material and methods. For the purpose of obtaining respective researching material, a diagnostic survey method was applied; the technique was based on surveying with the self-prepared questionnaire as a tool. The study also used a standardized questionnaire of attitudes to life, which consisted of 10 statements. The study was conducted among 80 students of nursing faculty and 80 students of the faculty of economics at the State Higher Vocational School in Ciechanów. The respondents were characterized in accordance with the following categories: gender, age, place of residence and religious activity.

Results. The analysis of the research material indicated that students' attitudes (both nursing and economy faculty students) partially affect their attitude to abortion. 53\% of the total number of students surveyed were opposed to abortion. A similar number of respondents had a neutral attitude to abortion, while 55\% which is more than half were not in favour of abortion being legalized in Poland. 61.2\% which was more than half of the students surveyed (both nursing and economy) felt that abortion was a murder committed upon the unborn child. The opposite statement was shared by $13.1 \%$ of respondents.

$67 \%$ of the respondents agreed with the statement that life begins at conception, while the opposite view was shared by only $10.4 \%$ of the respondents. $67,5 \%$ of the total number of students think that abortion is nothing else but depriving the child of the right to live.

The overwhelming majority of $70.6 \%$ respondents believed that abortion should be allowed when it is a threat to the mother's or a child's health or life.

As many as $66 \%$ of students believe that the procedure of abortion should be permitted when there is a risk of severe damage to the foetus or an incurable disease. At the same time $59.4 \%$ of the respondents expressed their support for abortion when it was a result of a criminal offense. Those who declared their religious faith and opposed the idea of legalizing abortion in Poland amounted to 58.4\%, as well as $9.1 \%$ of respondents not declaring their religious faith also expressed this attitude of not supporting abortion legalization. More than a half of non-religious students i.e. $63.7 \%$ were in favour of the abortion legalization, which was also the outlook of $23.5 \%$ of the religious respondents. Women more often than men refer negatively to the idea of supporting legalization of abortion in Poland.

\section{Conclusions}

1. There is a discrepancy between the declared outlook and behaviour in terms of permissibility of pregnancy terminationin different situations.

2. The declared support for abortion significantly depends upon the particular situation.

3. Religion plays an important role as a factor of moral and social rights, which in consequence affects the declared views upon the bioethical issues.

4. There is a need to pay special attention to the issues of bioethics in the education of nursing students. 
5. Different measures such as social campaigns should be taken to raise awareness of young men on what the consequences of abortion for a woman are.

6. Further research should include a wider range of life attitudes than just a sense of purpose.

Słowa kluczowe: aborcja, studenci pielęgniarstwa, postawy życiowe, stosunek do aborcji

Keywords: abortion, nursing students, life attitudes, attitudes to abortion

\section{Wstęp}

Problemy natury medycznej, psychologicznej i społecznej związane z przerwaniem ciąży towarzyszą ludziom od zarania ludzkości. Już w zbiorze pism Hipokratesa, którego uważa się za ojca medycyny racjonalnej, znajduje się przysięga lekarska dotycząca zakazu przerywania ciąży, która brzmi następująco „żadnej kobiecie nie podam środka do spędzenia płodu” [1]. W Polsce w XVII wieku kobietom, które dokonały aktu przerwania ciąży groziła kara śmierci. Natomiast w okresie Królestwa Polskiego aborcja wykonana przez kobietę lub ojca dziecka była traktowana jako występek, i podlegała karze zamknięcia w domu na okres od 1 do 3 lat [2].

W okresie przypadającym na lata 1932 - 1956 wprowadzono prawny zakaz przerywania ciąży [3]. Pierwotnie obowiązujący projekt Kodeksu Karnego przewidywał karę dla kobiet, które podjęły się zabiegu aborcji a także dla osób, które go wykonały. Kara ta dla obydwu stron wynosiła do 5 lat pozbawienia wolności. Projekt ten był bardzo krytykowany przez prawników i lekarzy, dlatego dodano artykuł, który stanowił o bezkarności lekarza w sytuacji kiedy ciąża zagrażałaby życiu lub zdrowiu ciężarnej kobiety, jak również dobru jej rodziny. Ostateczna wersja projektu Kodeksu Karnego dopuszczała dokonanie przerwania ciąży w momencie, gdy kobieta znalazłaby się w ciężkiej sytuacji materialnej [3].

W 1956 r. rząd polski podjął decyzję legalizacji aborcji ze względów medycznych oraz społecznych [4]. 27 kwietnia 1956 r. Sejm uchwalił ustawę dotyczącą warunków dopuszczalności przerwania ciąży do 12 tygodnia w następujących sytuacjach:

- gdy ciąża jest skutkiem przestępstwa,

- gdy kobieta nie posiada środków materialnych niezbędnych do życia,

- ze wskazań lekarskich [5].

Trzy lata później Ministerstwo Zdrowia wydało kolejne rozporządzenie, które jeszcze bardziej umożliwiło dokonywanie przerywania ciąży, dając kobiecie możliwość ustnego oświadczenia, określającego jej trudną sytuację materialną, co stanowiło podstawę do wykonania aborcji [6].

W 1993 r. nastąpiła długo oczekiwana - prawna ochrona ludzkiego życia w okresie płodowym. Kwestię dotyczącą aborcji reguluje ustawa z 7 stycznia 1993 r. o planowaniu rodziny, ochronie płodu ludzkiego i warunkach dopuszczalności przerywania ciąży [3] Jak sama nazwa wskazuje głównym zadaniem ustawy z 1993 r. jest ochrona życia, a prawo do niego posiada każdy człowiek już od momentu poczęcia [7].

Dopuszcza ona możliwość przerwania ciąży tylko w następujących sytuacjach:

- jeżeli ciąża stanowi zagrożenie życia lub zdrowia ciężarnej kobiety,

- jeżeli po przeprowadzeniu badań prenatalnych lub innych przesłanek medycznych, które wskazują na duże prawdopodobieństwo ciężkiego oraz nieodwracalnego upośledzenia płodu lub nieuleczalnej choroby, która zagraża jego życiu,

- jeżeli istnieje uzasadnione podejrzenie iż ciąża powstała w wyniku przestępstwa.

Aktem prawnym, który reguluje wykonywanie zabiegu przerwania ciąży jest rozporządzenie Ministra Zdrowia i Opieki Społecznej z dnia 22 stycznia 1997 r. dotyczące 
kwalifikacji zawodowych lekarzy, którzy są uprawnieni do dokonania przerwania ciąży a także stwierdzenia iż ciąża zagraża życiu lub zdrowiu kobiety ciężarnej lub wskazuje na prawdopodobieństwo ciężkiego orz nieodwracalnego upośledzenia płodu lub nieuleczalnej choroby zagrażającej jego życiu (Dz. U. 1997, Nr 9, poz. 49). Rozporządzenie z dnia 13 lutego 1997 roku w sprawie kwalifikacji osób innych niż lekarz, które są uprawnione do przeprowadzenia konsultacji z ciężarną kobietą, która planuje dokonać aborcji, określa zasady tworzenia list osób konsultujących a także sposobu oraz tryb przeprowadzenia tych konsultacji (Dz. U. 1997, Nr 18, poz. 104). Listę osób uprawnionych do komunikowania się z ciężarną kobietą, która chce dokonać zabiegu przerwania ciąży tworzy wojewoda [8].

Aborcja (łac. abortus) to zabieg mający na celu przerwanie ciąży, ludzkiego życia w okresie płodowym (wewnątrzmacicznym) [9]. Określana jest też jako „sztuczne poronienie”, „skrobanka”. Przerwanie ciąży to działanie celowe i zamierzone, mające na celu zniszczenie ludzkiego życia [10]. Podczas wykonywania zabiegu aborcji podejmowane są działania, które mają na celu zakłócić prawidłowy przebieg ciąży, co w konsekwencji prowadzi do śmierci poczętego zarodka lub płodu [11].

Istnieje wiele metod dokonywania zabiegu aborcji. Wyróżnia się główne dwie kategorie przerwania ciąży: chirurgiczne i farmakologiczne.

W czasie aborcji chirurgicznej zawartość macicy, w której rozwija się zarodek zostaje usunięta. Przy zastosowaniu chirurgicznego usunięcia ciąży metoda postępowania zależna jest od stopnia zaawansowania ciąży, kwalifikacji osoby przeprowadzającej zabieg, preferowanego podejścia w lokalnym środowisku medycznym, a także od dostępności sprzętu medycznego.

Do metod farmakologicznych zaliczamy stosowanie pigułki Mifepriston (RU 486), podawanej doustnie w dawce $600 \mathrm{mg}$ [12]. Po zastosowaniu tej metody u niewielkiego odsetka kobiet, konieczne jest opróżnienie zawartości macicy z pozostałych resztek łożyska oraz płodu. Aborcję farmakologiczną stosuje się od momentu rozpoznania ciąży, ale nie później niż do 9 tygodnia ciąży [11]. W Polsce nie zarejestrowano jeszcze środków służących do aborcji farmakologicznej, jednak statystyki wskazują na to iż są one w Polsce osiągalne nielegalnie w tzw. „podziemiu aborcyjnym”[13].

Wśród młodych kobiet, czynnikami wpływającymi na podjęcie decyzji o przerwaniu ciąży jest lęk przed napiętnowaniem społeczeństwa, a także wstyd, który wiąże się z niechcianą ciążą. Dziewczęta, które nieplanowo zaszły w ciążę boją się odrzucenia rodziców i partnera, obawiają się również wydalenia ze szkoły. Często na podjęcie trudnej decyzji wpływają sami rodzice, sugerując przerwanie ciąży jako sposobu rozwiązania niewygodnej sytuacji [14].

Specjaliści zaznaczają, że na podjęcie decyzji o usunięciu płodu istotny wpływ mają postawy wobec samej aborcji, małżeństwa i współżycia seksualnego, które są następstwem oddziaływań rodzinnych i społecznych. Dlatego tak istotne jest wprowadzanie edukacji zdrowotnej do szkół, polityki prorodzinnej, wspierającej więź i komunikację pomiędzy członkami rodziny, a młodą kobietą zapewniając jej odpowiednią ochronę . Jest to bardzo ważne dla dorastającej młodzieży, której przeżycia życiowe i zdolności poznawcze są jeszcze niewystarczająco ukształtowane [15].

Celem badań było poznanie postaw życiowych studentów pielęgniarstwa i ich wpływu na stosunek studentów do aborcji.

\section{Materiał i metody}

W celu zebrania materiału badawczego zastosowano metodę sondażu diagnostycznego przy użyciu techniki ankietowania. Narzędzie badawcze stanowił autorski kwestionariusz ankiety. 
Analizie poddano 180wypełnionych ankiet. W pracy zastosowano celowy dobór grupy. Badania przeprowadzono na terenie dwóch Wydziałów Państwowej Wyższej Szkoły Zawodowej w Ciechanowie: na Wydziale Ochrony Zdrowia i Nauk Humanistycznych, kierunku pielęgniarstwo, gdzie studenci stanowili grupę badawczą i na Wydziale Inżynierii i Ekonomii, kierunku ekonomia, gdzie studenci stanowili grupę kontrolną.

Ankietowanych scharakteryzowano pod względem płci, wieku, miejsca zamieszkania i aktywności religijnej.

W badaniu udział wzięło ogółem 160 studentów. Grupa charakteryzowała się równomiernym rozkładem, jeśli chodzi o płeć: 80 kobiet (50\%) oraz 80 mężczyzn (50\%). Kierunek pielęgniarstwo reprezentowany był przez 80 studentów gdzie (50\%) stanowiły kobiety i (50\%) stanowili mężczyźni, identyczny stosunek studentów odnotowano na kierunku ekonomia. Zdecydowana większość ankietowanych studentów była w przedziale wiekowym od 19 do 25 roku życia i stanowili oni $(95,6 \%)$, niewielką grupę stanowili respondenci w wieku od 26 i powyżej 4,4 \%.Większość respondentów - 60,6\% to mieszkańcy wsi, natomiast 39,4\% studentów mieszka w mieście do 100 tysięcy mieszkańców, 5\% respondentów to mieszkańcy miasta powyżej 100 tysięcy mieszkańców. Zdecydowana większość respondentów (93,1\%) to osoby deklarujące się jako wierzące, natomiast osoby niewierzące to jedynie 6,9\% spośród wszystkich ankietowanych.

Ankietowani studenci - 48,1 \% uważają, że wyznanie, przekłada się na poglądy i decyzje podejmowane $w$ życiu codziennym, zdecydowanie inne zdanie posiada $26,2 \%$ studentów, natomiast $25,7 \%$ studentów nie posiada zdania na ten temat.

\section{Wyniki}

\section{Opinie badanych na temat aborcji i jej legalizacji}

Wyniki, które otrzymano poddano analizie ilościowej w celu określenia ogólnego poziomu stosunku do aborcji i postaw życiowych. Średni wynik wyniósł 29 przy odchyleniu standardowym $\mathrm{SD}=8,2$. Aby stwierdzić czy badani respondenci są zwolennikami, przeciwnikami lub mają neutralny stosunek określony został próg punktów, który wskazywał na stosunek do aborcji. Respondent maksymalnie mógł uzyskać 50 punktów w toku wypełnienia pierwszej części ankiety. Ustalono następujące zależności: liczba punktów do 25 wskazywała na przeciwnika aborcji, liczba od 26 do 35 stosunek neutralny, natomiast powyżej 35 punktów respondent był zwolennikiem aborcji. W 3 pytaniach zastosowano odwrócenie skali, gdzie 1 oznaczało 5 natomiast 5 oznaczało 1 . Były to następujące stwierdzenia: aborcja jest zabójstwem dokonanym na nienarodzonym człowieku, życie ludzkie zaczyna się w momencie poczęcia oraz aborcja jest pozbawieniem prawa dziecka do życia.

Wśród 160 studentów 52 osoby (32,5\%) były przeciwnikami aborcji, 68 studentów $(42,5 \%)$ miało neutralny stosunek, natomiast 40 studentów obu kierunków (25\%) było zwolennikami aborcji. Większość ankietowanych 55\% opowiedziała się przeciwko legalizacji aborcji, za legalizacją aborcji opowiedziało się $26,2 \%$, natomiast $18,8 \%$ nie posiada zdania na ten temat. Spośród badanej grupy studentów 61,2\% zdecydowanie lub raczej zgodziła się ze stwierdzeniem, że aborcja jest zabójstwem dokonanym na nienarodzonym dziecku. 25,5\% ankietowanych studentów zdecydowanie lub raczej nie zgadza się z tym stwierdzeniem. Odpowiedzi ani się zgadzam ani się nie zgadzam udzieliło 13,1\% respondentów. Zdecydowana większość badanych studentów 67 \% zgodziła się z ze stwierdzeniem, że życie ludzkie zaczyna się w momencie poczęcia. Odpowiedzi ani się zgadzam ani się nie zgadzam udzieliło 13,8\% respondentów. Natomiast 10,4 \% ankietowanych badanej grupy zdecydowanie lub raczej nie 
zgadza się $\mathrm{z}$ tym stwierdzeniem. Analiza wyników opinii studentów, że aborcja jest pozbawieniem prawa dziecka do życia wykazała, że zdecydowana większość 67,5\% badanych zdecydowanie lub raczej zgadza się z powyższym stwierdzeniem. 13,1\% studentów kierunku pielęgniarstwa i ekonomii ani się zgadza ani się nie zgadza z tym stwierdzeniem, natomiast zdecydowanie lub raczej nie zgadza się z tym stwierdzeniem 19,4\% badanych studentów kierunku pielęgniarstwa i ekonomii. Analiza wyników badań dotyczących opinii studentów dotyczących stwierdzenia, że zarodek to nie człowiek ale zygota wykazała, że ponad połowa respondentów - 52,5\% zdecydowanie lub raczej nie zgadza się z powyższym stwierdzeniem. Zdecydowanie lub raczej zgadza się z powyższym stwierdzeniem $23,1 \%$ badanych studentów pielęgniarstwa i ekonomii, natomiast $24,4 \%$ studentów pielęgniarstwa i studentów ekonomii ani się zgadza ani się nie zgadza z tym stwierdzeniem.

Stwierdza się wysoki procent dopuszczalności aborcji w opinii studentów w momencie kiedy stanowi ona zagrożenie dla zdrowia lub życia matki. 61 osób zdecydowanie zgadza się z dopuszczalnością przerwania ciąży, gdy jest ona zagrożeniem dla zdrowia i życia matki oraz 52 osoby raczej zgadzają się z tym stwierdzeniem. Podobny rozkład odpowiedzi w opinii respondentów dotyczył dopuszczalności aborcji, gdy istnieje możliwość upośledzenia płodu oraz gdy powstała ona w momencie dokonania czynu zabronionego na kobiecie. 94 respondentów zdecydowanie lub raczej zgadza się z dopuszczalnością aborcji, gdy stanowi ona upośledzenie płodu, natomiast 95 badanych zdecydowanie lub raczej zgadza się, aby zabieg przerwania ciąży był dopuszczalny w momencie, gdy powstał w wyniku np. gwałtu.

\section{Wyznanie studentów a stosunek wobec aborcji}

Wyznanie studentów wpływa istotnie na wyniki w skali stosunku do aborcji. Średni wynik osób deklarujących wyznawaną wiarę wynosi 28,31 przy odchyleniu standardowym 7,85 natomiast średni wynik osób niewierzących wyniósł 39,36 przy odchyleniu standardowym 5,35. Różnice nie są istotne statystycznie $(\mathrm{p}<0,05)$.

Tabela 1. Wyznawana wiara a stosunek do aborcji

\begin{tabular}{|c|c|c|c|c|}
\hline & Osoby wierzące & $\begin{array}{c}\text { Osoby } \\
\text { niewierzące }\end{array}$ & $\mathrm{t}$ & $\mathrm{p}$ \\
\hline $\begin{array}{c}\text { Stosunek do } \\
\text { aborcji }\end{array}$ & 28,31 & 39,66 & 4,581 & 0,000 \\
\hline
\end{tabular}

$\mathrm{df}=158, \mathrm{p}<0,05$

Źródło: wynik badań własnych

Większość respondentów deklarujących wiarę 58,4\% zdecydowanie lub raczej nie opowiadała się za legalizacją aborcji, natomiast wśród niewierzących respondentów zaledwie $9,1 \%$ badanych nie opowiadała się za legalizacją aborcji w Polsce. Ani się zgadza ani się nie zgadza na legalizację aborcji 21,5\% ankietowanych wierzących i 27,3\% ankietowanych niewierzących. Zdecydowanie lub raczej za legalizacją aborcji opowiada się 23,5\% wierzących oraz ponad połowa niewierzących $-63,7 \%$. 
Tabela 2. Wyznawana wiara a legalizacja aborcji w opinii ankietowanych

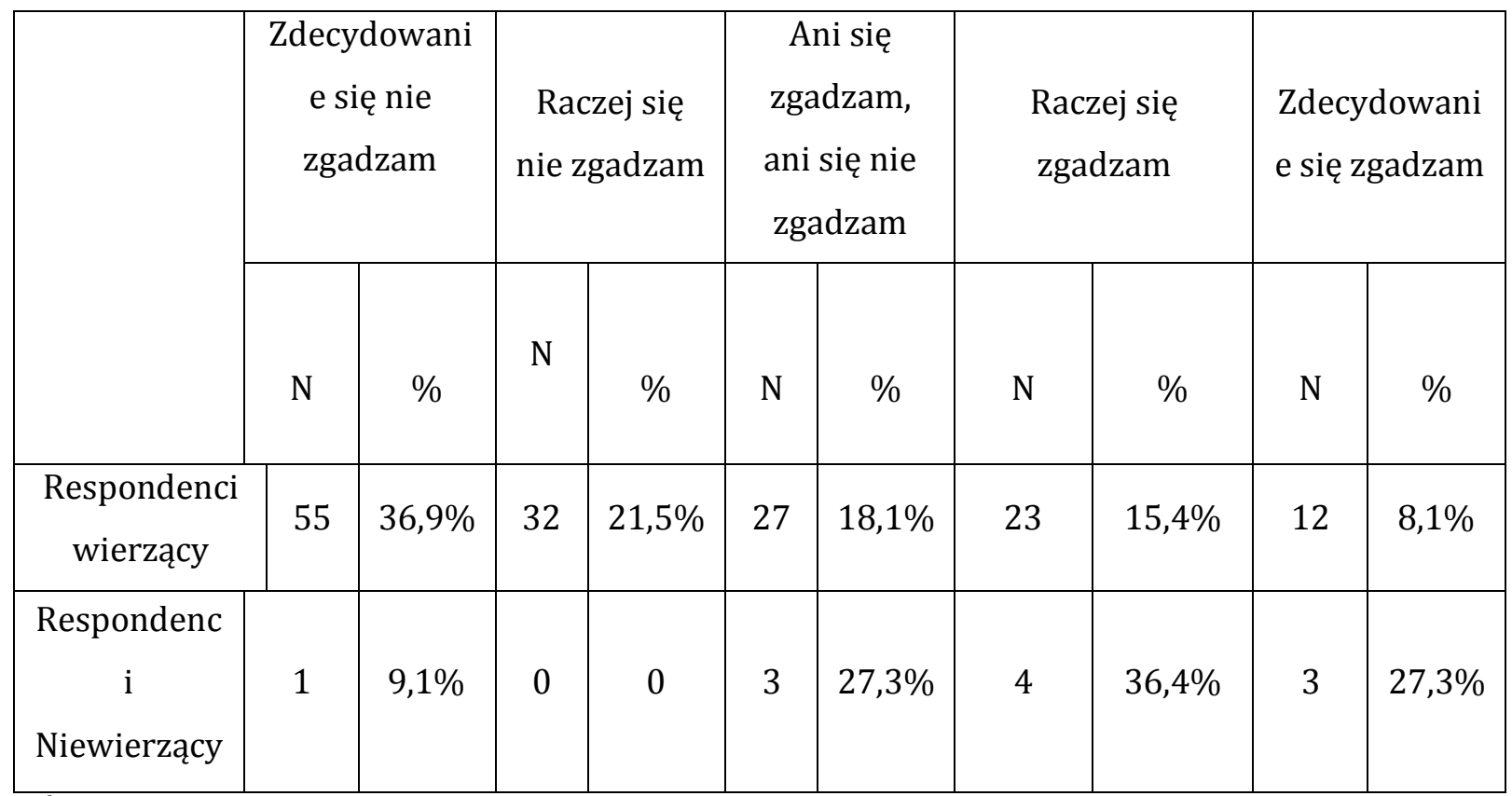

Źródło: wynik badań własnych

Analiza wyników badań dotyczących opinii studentów, że aborcja jest pozbawieniem prawa dziecka do życia wykazała, że zdecydowana większość 71,8\% respondentów wierzących zdecydowanie lub raczej zgadza się z tym stwierdzeniem, natomiast tylko 9,1\% respondentów niewierzących zdecydowanie nie zgadza się z tym stwierdzeniem.

Z powyższym stwierdzeniem ani się zgadza ani się nie zgadza 10,1\% studentów wierzących i 54,5\% studentów niewierzących. Zdecydowanie lub raczej nie zgadza się 18,1\% badanych deklarujących wiarę oraz 36,4\% respondentów nie deklarujących swojej wiary.

Tabela 3. Wyznawana wiara a aborcja jako pozbawienie praw do życia dziecka

\begin{tabular}{|c|c|c|c|c|c|c|c|c|c|c|}
\hline & \multicolumn{2}{|c|}{$\begin{array}{c}\text { Zdecydowanie } \\
\text { się nie } \\
\text { zgadzam }\end{array}$} & \multicolumn{2}{|c|}{$\begin{array}{l}\text { Raczej się } \\
\text { nie } \\
\text { zgadzam }\end{array}$} & \multicolumn{2}{|c|}{$\begin{array}{c}\text { Ani się } \\
\text { zgadzam, ani } \\
\text { się nie } \\
\text { zgadzam }\end{array}$} & \multicolumn{2}{|c|}{$\begin{array}{l}\text { Raczej się } \\
\text { zgadzam }\end{array}$} & \multicolumn{2}{|c|}{$\begin{array}{c}\text { Zdecydowanie } \\
\text { się zgadzam }\end{array}$} \\
\hline & $\mathrm{N}$ & $\%$ & $\mathrm{~N}$ & $\%$ & $\mathrm{~N}$ & $\%$ & $\mathrm{~N}$ & $\%$ & $\mathrm{~N}$ & $\%$ \\
\hline $\begin{array}{c}\text { Respondenci } \\
\text { wierzący }\end{array}$ & 13 & $8,7 \%$ & 14 & $9,4 \%$ & 15 & $10,1 \%$ & 32 & $21,5 \%$ & 75 & $50,3 \%$ \\
\hline $\begin{array}{l}\text { Respondenci } \\
\text { niewierzący }\end{array}$ & 4 & $36,4 \%$ & 0 & 0 & 6 & $54,5 \%$ & 1 & $9,1 \%$ & 0 & 0 \\
\hline
\end{tabular}

Źródło: wynik badań własnych 


\section{Postawy życiowe badanych studentów}

Badani respondenci uzyskali stosunkowo wysokie wyniki w skali postaw życiowych (poczucia celowości) tzn., że charakteryzowali się wysokim poziomem postrzegania swojej wolności do podejmowania wszelkich życiowych decyzji i posiadali wysoką odpowiedzialność za decyzje, które podejmowali w życiu. Maksymalna ilość punktów, którą respondenci mogli otrzymać po wypełnieniu Kwestionariusza Postaw Życiowych (dalej: KPŻ) wynosił 56 punktów. W skali postaw życiowych studenci pielęgniarstwa uzyskali średni wynik 45,21 przy odchyleniu standardowym 6,98, natomiast studenci ekonomii uzyskali średni wynik 46,00 przy odchyleniu standardowym 6,77.

Tabela 4. Postawy życiowe a kierunek studiów

\begin{tabular}{|l|c|c|c|c|}
\hline & Pielęgniarstwo & Ekonomia & $\mathrm{t}$ & $\mathrm{P}$ \\
\hline Postawy życiowe & 45,21 & 46,00 & $-0,727$ & 0,470 \\
\hline
\end{tabular}

$\mathrm{df}=158, \mathrm{p}<0,05$

Źródło: wynik badań własnych

Zarówno studenci pielęgniarstwa i ekonomii uzyskali najwyższe wyniki w KPŻ w następujących stwierdzeniach: możliwość kierowania moim własnym życiem uważam za bardzo ważną, ja sam decyduję o tym co dzieje się w moim życiu, moje życie jest w moich rękach i mam nad nim kontrolę, przyjmuję osobistą odpowiedzialność za decyzje, które podejmuję w swoim życiu. Powyższe postawy życiowe istotnie wpływają na stosunek respondentów do aborcji.

Zdecydowana większość respondentów 86,2\% twierdzi że możliwość kierowania własnym życiem uważa za bardzo ważną. Odpowiedzi, że raczej jest to prawda udzieliło 7,5\% badanych studentów. Nie ma zdania na ten temat 1,9\%. Odpowiedzi, że raczej jest to nieprawda udzieliło 0,6\% respondentów, natomiast 3,8\% badanych studentów całkowicie nie zgodziła się z powyższym stwierdzeniem.

Tabela 5. Możliwość kierowania własnym życiem

\begin{tabular}{|c|c|c|c|c|c|c|c|c|c|c|}
\hline & \multicolumn{2}{|c|}{$\begin{array}{l}\text { Całkowicie } \\
\text { nieprawda }\end{array}$} & \multicolumn{2}{|c|}{$\begin{array}{c}\text { Raczej } \\
\text { nieprawda }\end{array}$} & \multicolumn{2}{|c|}{$\begin{array}{c}\text { Nie mam } \\
\text { zdania }\end{array}$} & \multicolumn{2}{|c|}{$\begin{array}{c}\text { Raczej } \\
\text { prawda }\end{array}$} & \multicolumn{2}{|c|}{$\begin{array}{c}\text { Całkowicie } \\
\text { prawda }\end{array}$} \\
\hline & $\mathrm{N}$ & $\%$ & $\mathrm{~N}$ & $\%$ & $\mathrm{~N}$ & $\%$ & $\mathrm{~N}$ & $\%$ & $\mathrm{~N}$ & $\%$ \\
\hline Respondenci & 6 & $3,8 \%$ & 1 & $0,6 \%$ & 3 & $1,9 \%$ & 12 & $7,5 \%$ & 138 & $86,2 \%$ \\
\hline
\end{tabular}

Źródło: wynik badań własnych 
Analiza materiału badawczego wykazała, że 60\% ankietowanych studentów pielęgniarstwa i ekonomi sama decyduje o tym, co dzieje się w ich życiu. $25 \%$ badanych studentów w odniesieniu do zadanego pytania stwierdziła, że jest to raczej prawda. Zdania na ten temat nie posiada $4,4 \%$ przebadanych respondentów. Odpowiedzi, że jest to raczej nieprawda udzieliło 7,5\% studentów, natomiast 3,1\% ankietowanych studentów zdeklarowało, że to stwierdzenie nie odnosi się do nich.

Tabela 6. Samodzielność w podejmowaniu decyzji

\begin{tabular}{|c|c|c|c|c|c|c|c|c|c|c|}
\hline & \multicolumn{2}{|c|}{$\begin{array}{l}\text { Całkowicie } \\
\text { nieprawda }\end{array}$} & \multicolumn{2}{|c|}{$\begin{array}{c}\text { Raczej } \\
\text { nieprawda }\end{array}$} & \multicolumn{2}{|c|}{$\begin{array}{c}\text { Nie mam } \\
\text { zdania }\end{array}$} & \multicolumn{2}{|c|}{$\begin{array}{l}\text { Raczej } \\
\text { prawda }\end{array}$} & \multicolumn{2}{|c|}{$\begin{array}{c}\text { Całkowicie } \\
\text { prawda }\end{array}$} \\
\hline & $\mathrm{N}$ & $\%$ & $\mathrm{~N}$ & $\%$ & $\mathrm{~N}$ & $\%$ & $\mathrm{~N}$ & $\%$ & $\mathrm{~N}$ & $\%$ \\
\hline Respondenci & 5 & $3,1 \%$ & 12 & $7,5 \%$ & 7 & $4,4 \%$ & 40 & $25 \%$ & 96 & $60 \%$ \\
\hline
\end{tabular}

Źródło: wynik badań własnych

\section{Kierunek studiów a poglądy i postawy życiowe studentów wobec aborcji}

Kierunek studiów nie wpływa istotnie na wyniki respondentów w skali stosunku do aborcji. Średni wynik studentów pielęgniarstwa wyniósł 29,15 przy odchyleniu standardowym 8,41, natomiast średni wynik badanych studentów ekonomii wyniósł 29,00 przy odchyleniu standardowym 8,01. Różnice nie są istotne statystycznie ( $p>0,05)$.

Kierunek studiów nie wpływa istotnie na wyniki respondentów w skali postaw życiowych. Średni wynik studentów pielęgniarstwa wyniósł 45,21 przy odchyleniu standardowym 6,98, natomiast średni wynik badanych studentów ekonomii wyniósł 46,00 przy odchyleniu standardowym 6,77. Różnice nie są istotne statystycznie (p>0,05).

Tabela 7. Stosunek do aborcji i postawy życiowe a kierunek studiów

\begin{tabular}{|c|c|c|c|c|}
\hline & Pielęgniarstwo & Ekonomia & $\mathrm{t}$ & $\mathrm{p}$ \\
\hline $\begin{array}{c}\text { Stosunek do } \\
\text { aborcji }\end{array}$ & 29,15 & 29,00 & 0,115 & 0,908 \\
\hline Postawy życiowe & 45,21 & 46,00 & $-0,727$ & 0,470 \\
\hline
\end{tabular}

$\mathrm{df}=158, \mathrm{p}<0,05$

Źródło: wynik badań własnych

Ponad połowa - $65 \%$ badanych studentów pielęgniarstwa oraz 58,75\% studentów ekonomii zdecydowanie lub raczej zgodziła się, że aborcja jest zabójstwem dokonanym na nienarodzonym dziecku. Odpowiedzi, że ani się zgadzam ani się nie zgadzam udzieliło 12,5\% respondentów pielęgniarstwa i 13,75\% studentów ekonomii. Natomiast zdecydowanie lub raczej nie zgodziło się 23,75\% badanych studentów pielęgniarstwa i 27,5\% studentów ekonomii. 
Tabela 8. Aborcja jako zabójstwo na nienarodzonym dziecku w opinii studentów pielęgniarstwa i ekonomii

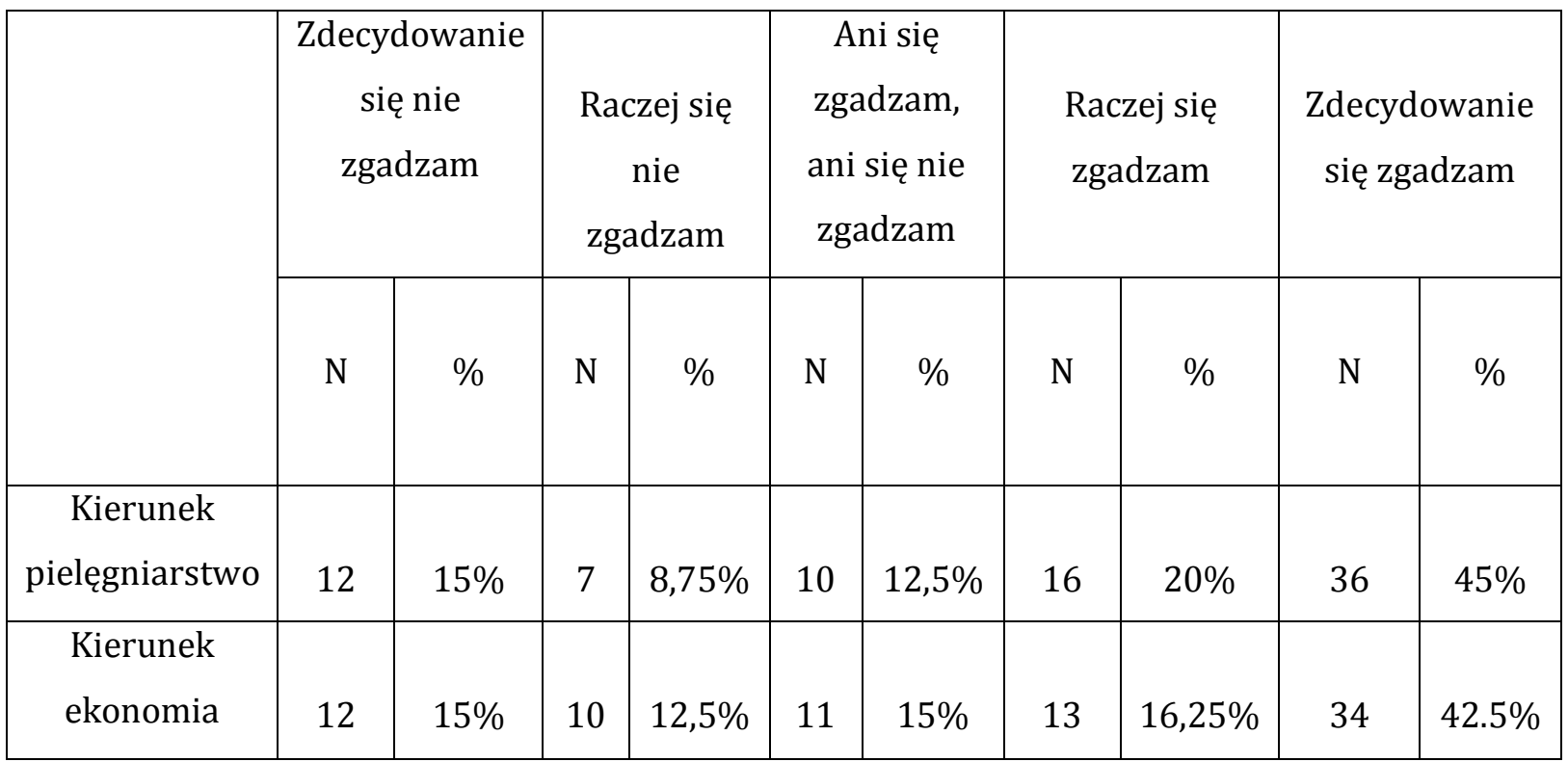

Źródło: wynik badań własnych

Zdecydowana większość studentów pielęgniarstwa bo aż 76,25\% oraz studentów ekonomii 67,5\% zdecydowanie lub raczej zgadza się ze stwierdzeniem, że aborcja jest procesem usunięcia niechcianego płodu. Odpowiedzi, że ani się zgadzam ani się nie zgadzam udzieliło $7,5 \%$ respondentów pielęgniarstwa i 12,5\% studentów ekonomii. Natomiast zdecydowanie lub raczej nie zgodziło się z tym stwierdzeniem - 16,25\% badanych studentów pielęgniarstwa i $20 \%$ studentów ekonomii.

Tabela 9. Aborcja jako proces usunięcia niechcianego płodu w opinii studentów pielęgniarstwa i ekonomii

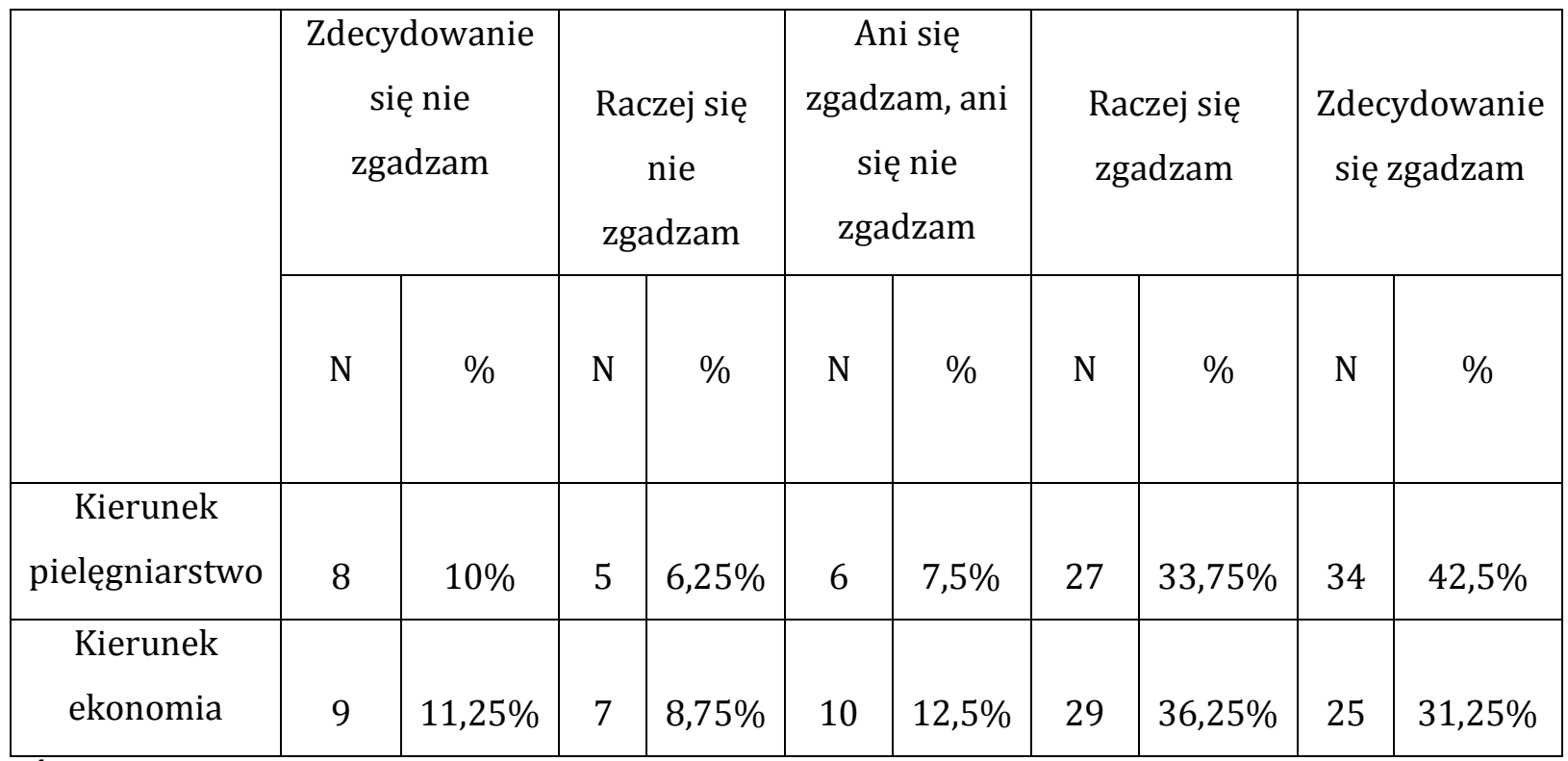

Źródło: wynik badań własnych 
Odpowiedzi studentów kierunku pielęgniarstwa i ekonomii na pytanie- czy są zwolennikami aborcji?, były zbieżne. Ponad połowa ogółu w obu grupach zdecydowanie lub raczej nie jest zwolennikiem aborcji. Zdecydowanie lub raczej nie zgadza się 28,75\% studentów pielęgniarstwa oraz $23,75 \%$ studentów ekonomii. Nie ma zdania na ten temat $16,25 \%$ badanych kierunku pielęgniarstwa oraz 23,75\% badanych kierunku ekonomii.

\section{Rycina 1. Poparcie aborcji w opinii ankietowanych studentów pielęgniarstwa i ekonomii}

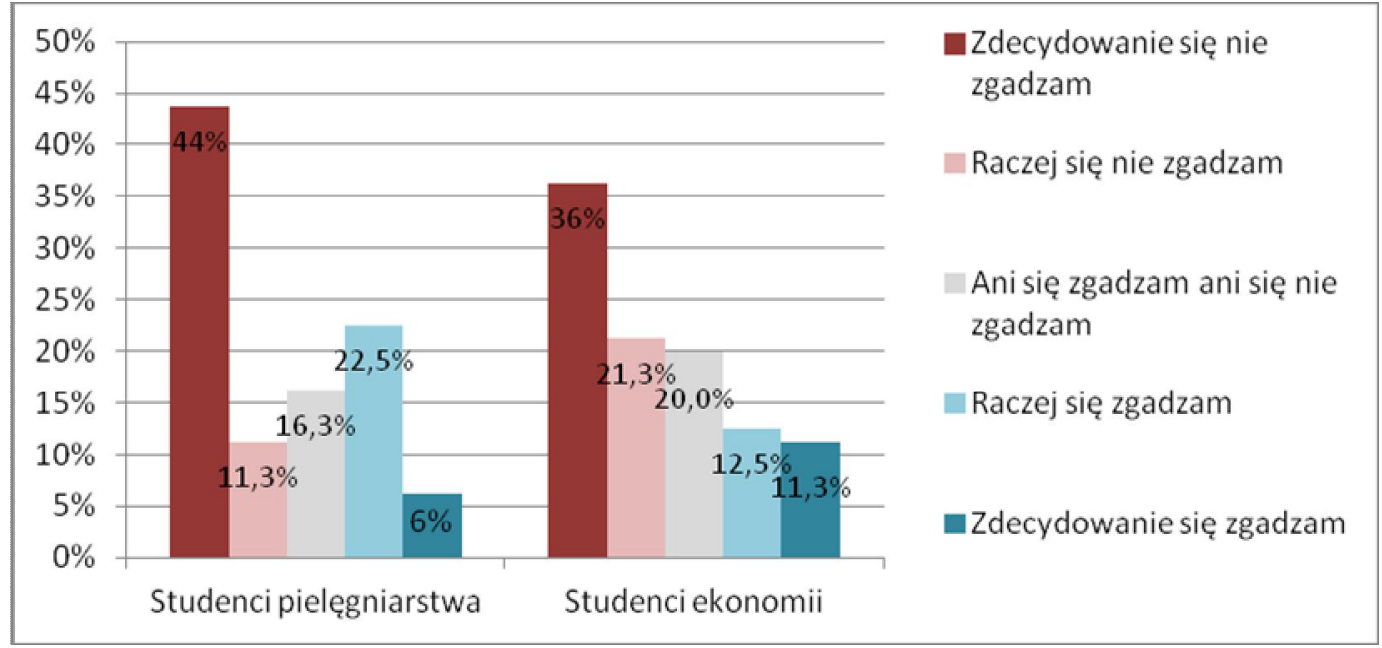

Źródło: wynik badań własnych

Opinie badanych studentów na temat legalizacji aborcji w Polsce pokrywały się z deklarowanym poparciem dla aborcji. Ponad połowa badanych zdecydowanie lub raczej nie zgadzała się na legalizację aborcji w Polsce. Zdecydowanie lub raczej opowiadała się ponad 1/3 ankietowanych studentów pielęgniarstwa 33,75\% oraz 17,5\% studentów ekonomii.

\section{Rycina 2. Opinia ankietowanych studentów na temat legalizacji aborcji w Polsce.}

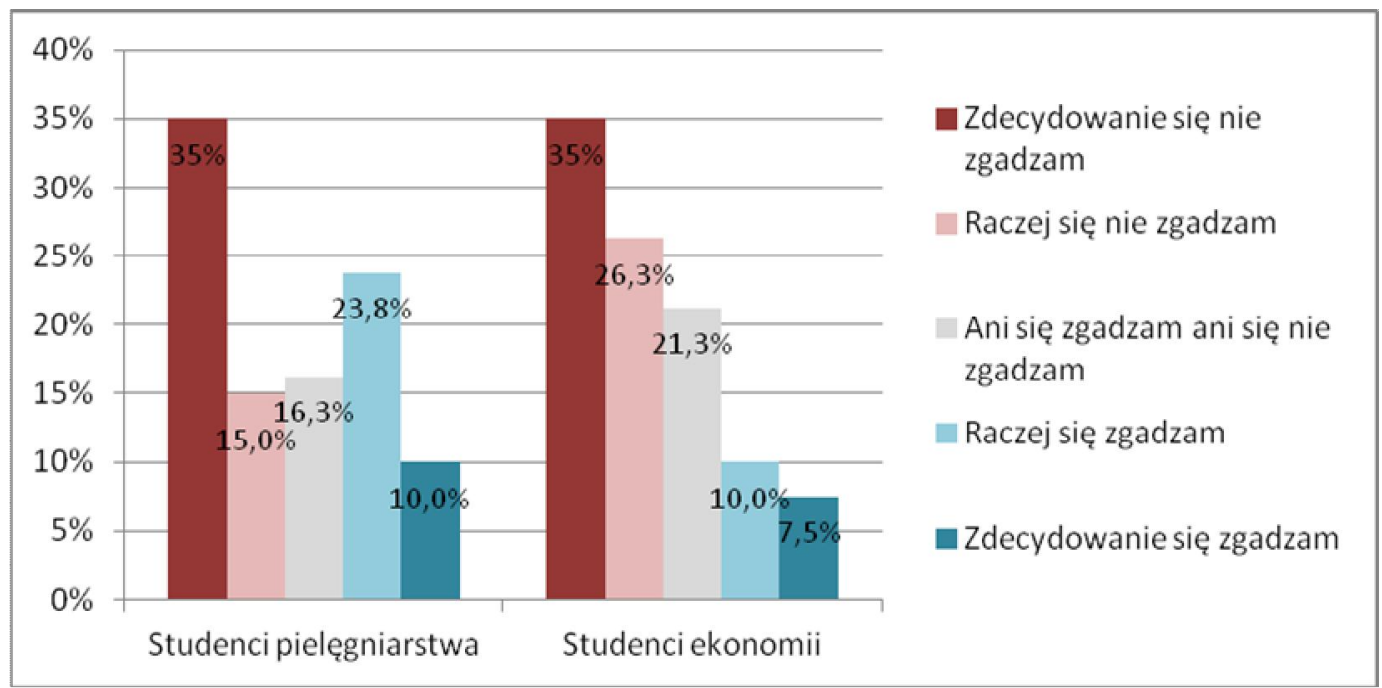

Źródło: wynik badań własnych 


\section{Płeć a poglądy i postawy życiowe studentów wobec aborcji}

Płeć wpływa istotnie na wyniki respondentów w skali stosunku do aborcji. Średni wynik respondentek wyniósł 27,55 przy odchyleniu standardowym 7,82, natomiast średni wynik respondentów wyniósł 30,60 przy odchyleniu standardowym 8,30. Różnice są istotne statystycznie $(\mathrm{p}<0,05)$.

Płeć nie wpływa istotnie na wyniki respondentów w skali postaw życiowych. Średni wynik respondentek wyniósł 44,70 przy odchyleniu standardowym 6,50, natomiast średni wynik respondentów wyniósł 46,51 przy odchyleniu standardowym 7,14. Różnice nie są istotne statystycznie $(\mathrm{p}>0,05)$.

Tabela 10. Stosunek do aborcji i postawy życiowe a płeć

\begin{tabular}{|c|c|c|c|c|}
\hline & Kobiety & Mężczyźni & $\mathrm{t}$ & $\mathrm{p}$ \\
\hline $\begin{array}{c}\text { Stosunek do } \\
\text { aborcji }\end{array}$ & 27,55 & 30,60 & $-2,390$ & 0,018 \\
\hline Postawy życiowe & 44,70 & 46,51 & $-1,677$ & 0,095 \\
\hline
\end{tabular}

$\mathrm{df}=158, \mathrm{p}<0,05$

Źródło: wynik badań własnych

Analiza wyników badań dotyczących opinii kobiet, że życie ludzkie zaczyna się w momencie poczęcia wykazała, że zdecydowana większość - 74,3\% kobiet zdecydowanie lub raczej zgadza się z powyższym stwierdzeniem. Podobne zdanie wyrazili mężczyźni - 57,5\%. Z powyższym stwierdzeniem ani się zgadza ani się nie zgadza $10 \%$ kobiet i 17,5\% mężczyzn. Zdecydowanie lub raczej nie zgadza się 13,8\% kobiet i 25\% mężczyzn.

Rycina 3. Opinia kobiet i mężczyzn na temat życia ludzkiego

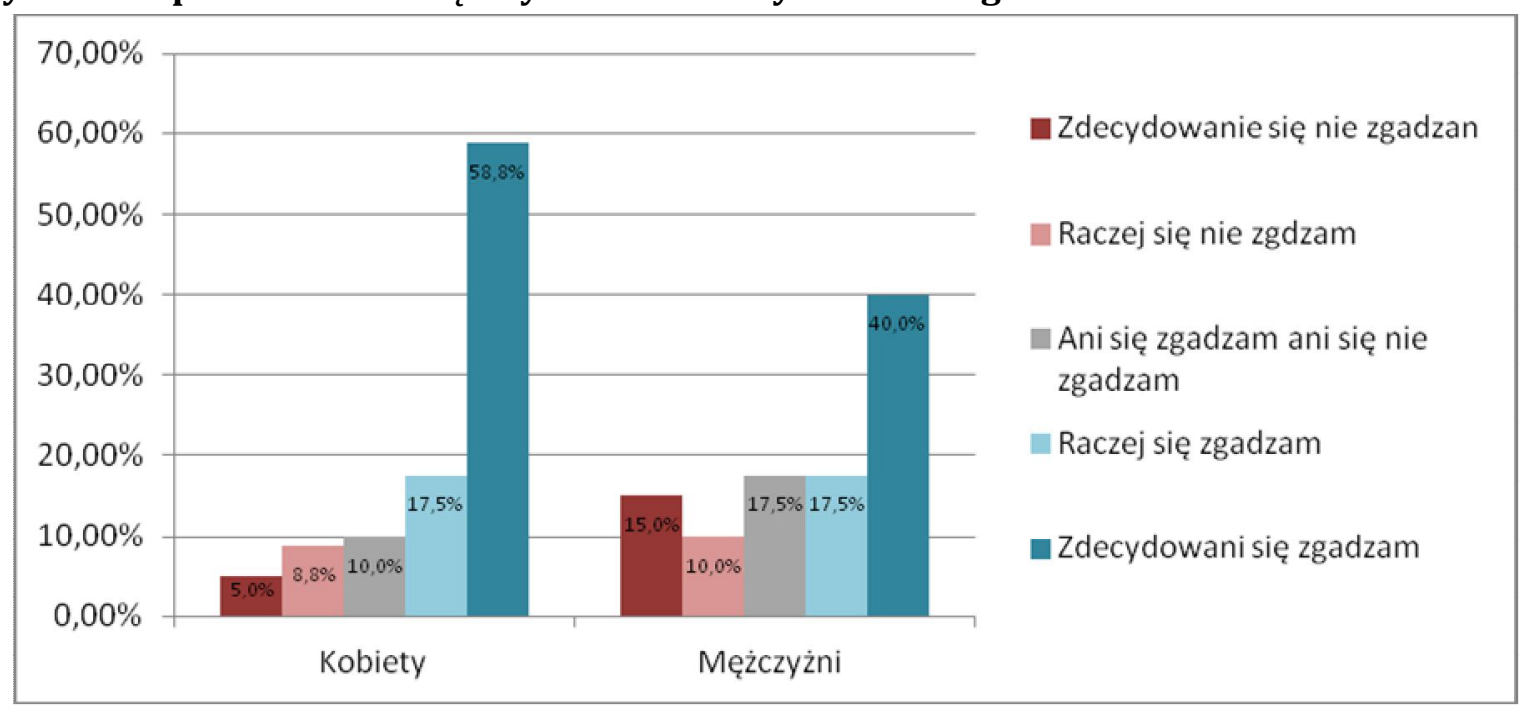

Źródło: wynik badań własnych

Zdecydowana większość badanych kobiet bo aż 76,3\% oraz 46,3\% mężczyzn odpowiadając na pytanie - czym jest dla nich aborcja, zdecydowanie lub raczej zgodziła się, że aborcja jest zabójstwem dokonanym na nienarodzonym dziecku. Odpowiedzi, że ani się zgadza ani się nie zgadza udzieliło 7,5\% kobiet i 18,8\% mężczyzn. Natomiast zdecydowanie lub raczej 
nie zgodziło się 16,3\% badanych kobiet z kierunku pielęgniarstwa i ekonomii i 35,1\% mężczyzn kierunku pielęgniarstwa i ekonomii.

Tabela 11. Aborcja jako zabójstwo na nienarodzonym dziecku w opinii kobiet i mężczyzn

\begin{tabular}{|c|c|c|c|c|c|c|c|c|c|c|}
\hline & \multicolumn{2}{|c|}{$\begin{array}{c}\text { Zdecydowanie } \\
\text { się nie } \\
\text { zgadzam }\end{array}$} & \multicolumn{2}{|c|}{$\begin{array}{c}\text { Raczej się } \\
\text { nie zgadzam }\end{array}$} & \multicolumn{2}{|c|}{$\begin{array}{c}\text { Ani się } \\
\text { zgadzam, ani } \\
\text { się nie } \\
\text { zgadzam }\end{array}$} & \multicolumn{2}{|c|}{$\begin{array}{l}\text { Raczej się } \\
\text { zgadzam }\end{array}$} & \multicolumn{2}{|c|}{$\begin{array}{c}\text { Zdecydowanie } \\
\text { się zgadzam }\end{array}$} \\
\hline & $\mathrm{N}$ & $\%$ & $\mathrm{~N}$ & $\%$ & $\mathrm{~N}$ & $\%$ & $\mathrm{~N}$ & $\%$ & $\mathrm{~N}$ & $\%$ \\
\hline Kobiety & 9 & $11,3 \%$ & 4 & $5 \%$ & 6 & $7,5 \%$ & 18 & $22,5 \%$ & 43 & $23,8 \%$ \\
\hline Mężczyźni & 15 & $18,8 \%$ & 13 & $16,3 \%$ & 15 & $18,8 \%$ & 11 & $13,8 \%$ & 26 & $32,5 \%$ \\
\hline
\end{tabular}

Źródło: wynik badań własnych

Ankietowani w większości w grupie kobiet- 72,6\% oraz w grupie mężczyzn - 71,3\% zdecydowanie lub raczej zgadzają się ze stwierdzeniem, że aborcja jest procesem usunięcia niechcianego płodu. Odpowiedzi, że ani się zgadza ani się nie zgadza udzieliło 11,3\% kobiet i 8,8\% mężczyzn. Natomiast zdecydowanie lub raczej nie zgodziło się 16,3\% badanych kobiet z kierunku pielęgniarstwa i ekonomii oraz 20,1 \% mężczyzn z kierunku pielęgniarstwa i ekonomii.

Tabela 12. Aborcja jako proces usunięcia niechcianego płodu w opinii kobiet i mężczyzn

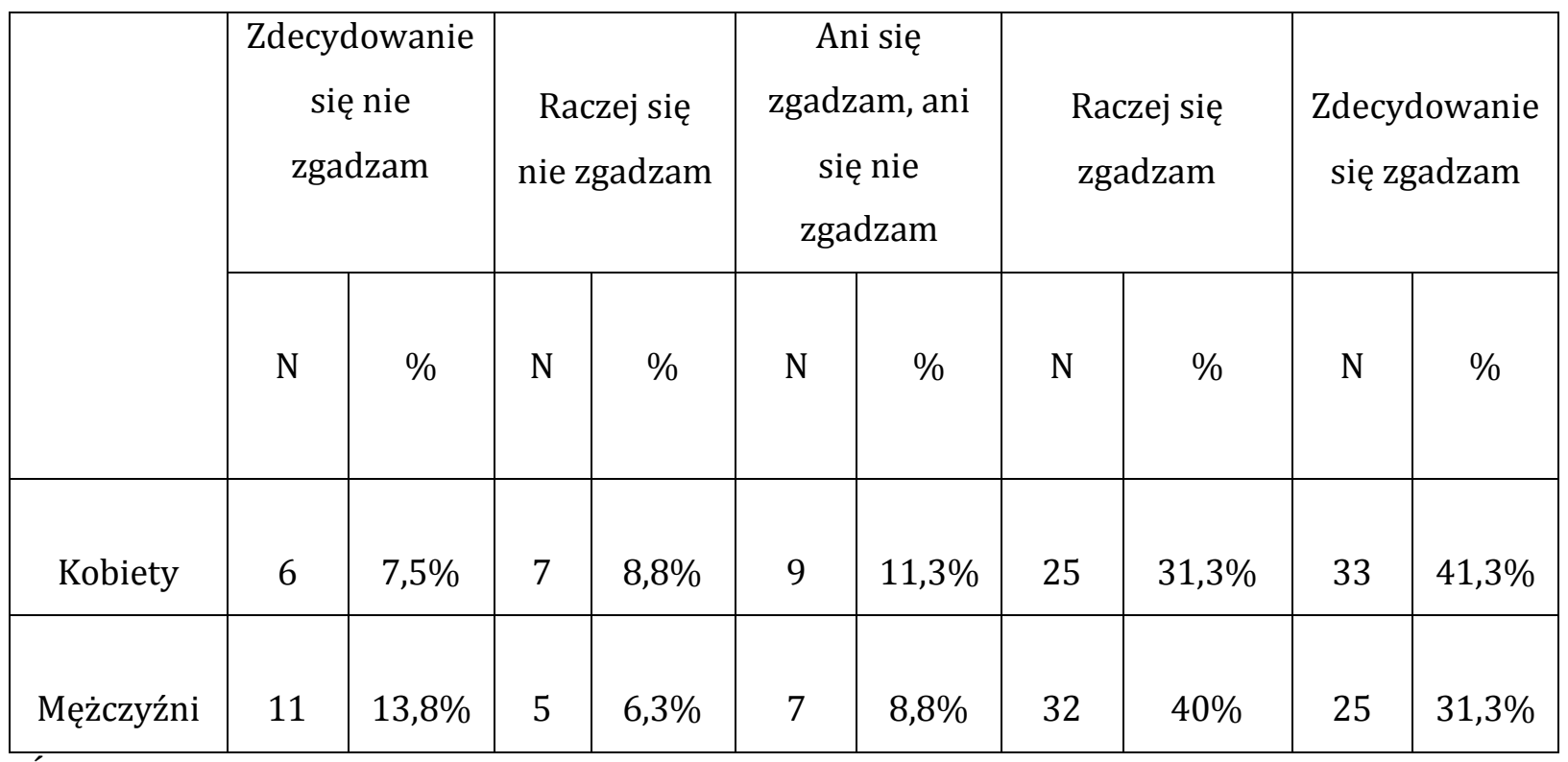

Źródło: wynik badań własnych 
Większość kobiet - 76,3\% oraz większość mężczyzn - 58,8\%, zdecydowanie lub raczej zgadza się ze stwierdzeniem, że aborcja jest pozbawieniem do praw życia dziecka. Odpowiedzi, że ani się zgadza ani się nie zgadza udzieliło 6,3\% ankietowanych kobiet i 20\%ankietowanych mężczyzn. Zdecydowanie lub raczej nie zgadza się z powyższym stwierdzeniem 17,6\% kobiet oraz 21,3\% mężczyzn.

Tabela 13. Aborcja jako pozbawienie praw do życia dziecka w opinii kobiet i mężczyzn

\begin{tabular}{|c|c|c|c|c|c|c|c|c|c|c|}
\hline & \multicolumn{2}{|c|}{$\begin{array}{c}\text { Zdecydowanie } \\
\text { się nie } \\
\text { zgadzam }\end{array}$} & \multicolumn{2}{|c|}{$\begin{array}{c}\text { Raczej się } \\
\text { nie zgadzam }\end{array}$} & \multicolumn{2}{|c|}{$\begin{array}{c}\text { Ani się } \\
\text { zgadzam, ani się } \\
\text { nie zgadzam }\end{array}$} & \multicolumn{2}{|c|}{$\begin{array}{l}\text { Raczej się } \\
\text { zgadzam }\end{array}$} & \multicolumn{2}{|c|}{$\begin{array}{c}\text { Zdecydowanie } \\
\text { się zgadzam }\end{array}$} \\
\hline & $\mathrm{N}$ & $\%$ & $\mathrm{~N}$ & $\%$ & $\mathrm{~N}$ & $\%$ & $\mathrm{~N}$ & $\%$ & $\mathrm{~N}$ & $\%$ \\
\hline Kobiety & 7 & $8,8 \%$ & 7 & $8,8 \%$ & 5 & $6,3 \%$ & 17 & $21,3 \%$ & 44 & $55 \%$ \\
\hline Mężczyźni & 10 & $12,5 \%$ & 7 & $8,8 \%$ & 16 & $20 \%$ & 16 & $20 \%$ & 31 & $38,8 \%$ \\
\hline
\end{tabular}

Źródło: wynik badań własnych

Wyniki uzyskane $\mathrm{z}$ wyrażenia przez badanych opinii na temat legalizacji aborcji w Polsce, pokrywały się z deklarowanym poparciem dla aborcji. Ponad połowa badanych 63,8\% kobiet oraz 56,3\% mężczyzn zdecydowanie lub raczej nie zgadzała się na legalizację aborcji w Polsce. Zdania na ten temat nie posiada $17,5 \%$ kobiet i $20 \%$ mężczyzn. Poparcie dla legalizacji aborcji w Polsce dopuszcza 18,8\% kobiet oraz 33,8\% mężczyzn.

\section{Rycina 4. Opinia kobiet i mężczyzn na temat legalizacji aborcji w Polsce}

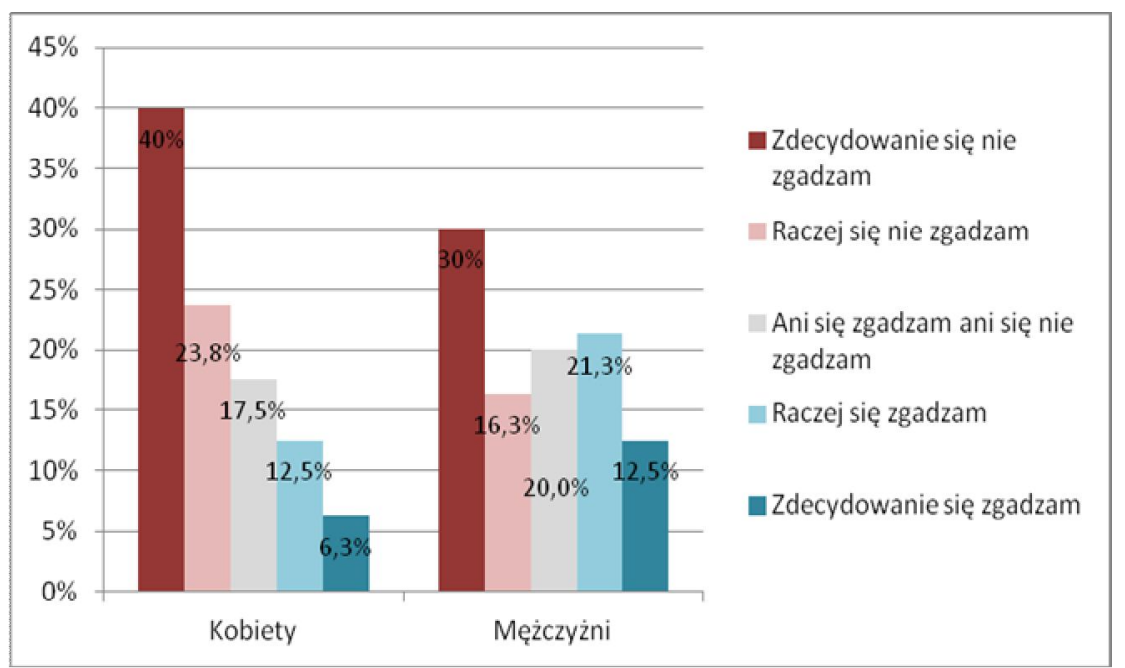

Źródło: wynik badań własnych 


\section{Wpływ postaw życiowych studentów pielęgniarstwa a ich stosunek do aborcji}

W celu zbadania zależności pomiędzy poziomem postaw życiowych studentów pielęgniarstwa a stosunkiem do aborcji zastosowano korelację r- Pearsona. W wyniku zastosowanych analiz stwierdzono brak istotnych statystycznie związków pomiędzy poziomem postaw życiowych studentów pielęgniarstwa a stosunkiem do aborcji. Poczucie celowości nie wpływa na poglądy studentów na temat przerywania ciąży ( $r$ - Pearsona $=-0,028, p=0,723$ ).

Aby określić czy poczucie celowości było na poziomie niskim, przeciętnym lub wysokim ustalono następującą punktację. Ankietowani, którzy charakteryzowali się niskim poczuciem celowości uzyskiwali od 8 do 35 punktów podczas wypełniania kwestionariusza. Badani, którzy uzyskali od 36 do 48 charakteryzowali się przeciętnym poczuciem celowości, natomiast respondenci, którzy uzyskali od 49 do 56 punktów charakteryzowali się wysokim poczuciem celowości. Wśród przebadanych studentów wyniki przedstawiały się następująco. Ponad połowa ankietowanych $-55,60 \%$ posiada przeciętne poczucie celowości. Niski poziom posiada 8,10\% badanych studentów, natomiast 35,30\% studentów charakteryzuję się wysokim poczuciem celowości.

Analizując wyniki przeprowadzonych badań nie zauważa się istotnie statystycznego związku dotyczącego kierunku studiów a poczuciem celowości. Niski poziom poczucia celowości posiada 7,50\% studentów pielęgniarstwa i 8,80\% studentów ekonomii. Przeciętnym poczuciem celowości charakteryzowała się grupa $63,80 \%$ ankietowanych kierunku pielęgniarstwo i 47,50\% ankietowanych kierunku ekonomia. Natomiast 28,80\% respondentów pielęgniarstwa i 43,80\% respondentów ekonomii charakteryzowało wysokie poczucie celowości w życiu.

\section{Rycina 5. Poczucie celowości a kierunek studiów}

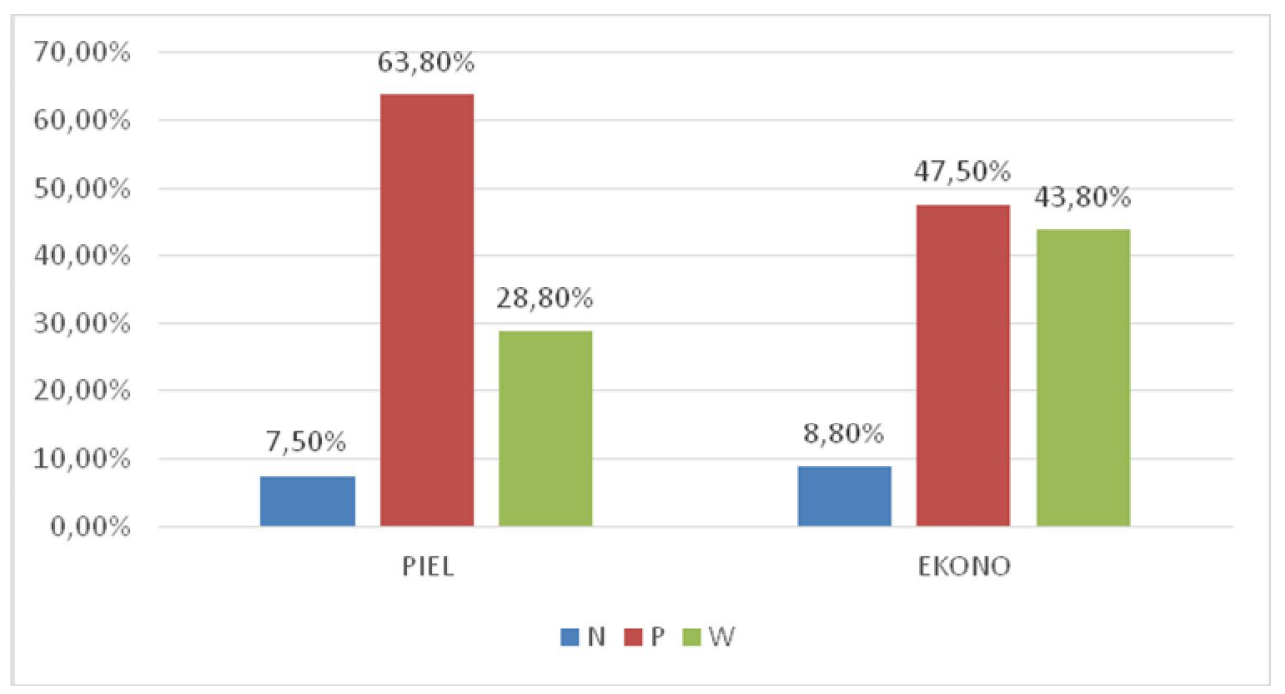

Źródło: wynik badań własnych

58,65\% badanych o wysokim poczuciu celowości nie zgadza się ze stwierdzeniem, że aborcja powinna być zalegalizowana. Podobnego zdania jest $52,8 \%$ badanych o przeciętnym poczuciu celowości i 53,9\% badanych o niskim poczuciu celowości. Zadeklarowanymi zwolennikami legalizacji jest $29,2 \%$ osób o przeciętnym poziomie postaw, 24,1\% o wysokim poziomie i tylko $15,4 \%$ osób o niskim poziomie. Osoby o niskim poziomie celowości najczęściej nie mają precyzowanego zdania $(30,8 \%)$. 


\section{Rycina 6. Poczucie celowości a legalizacja aborcji}

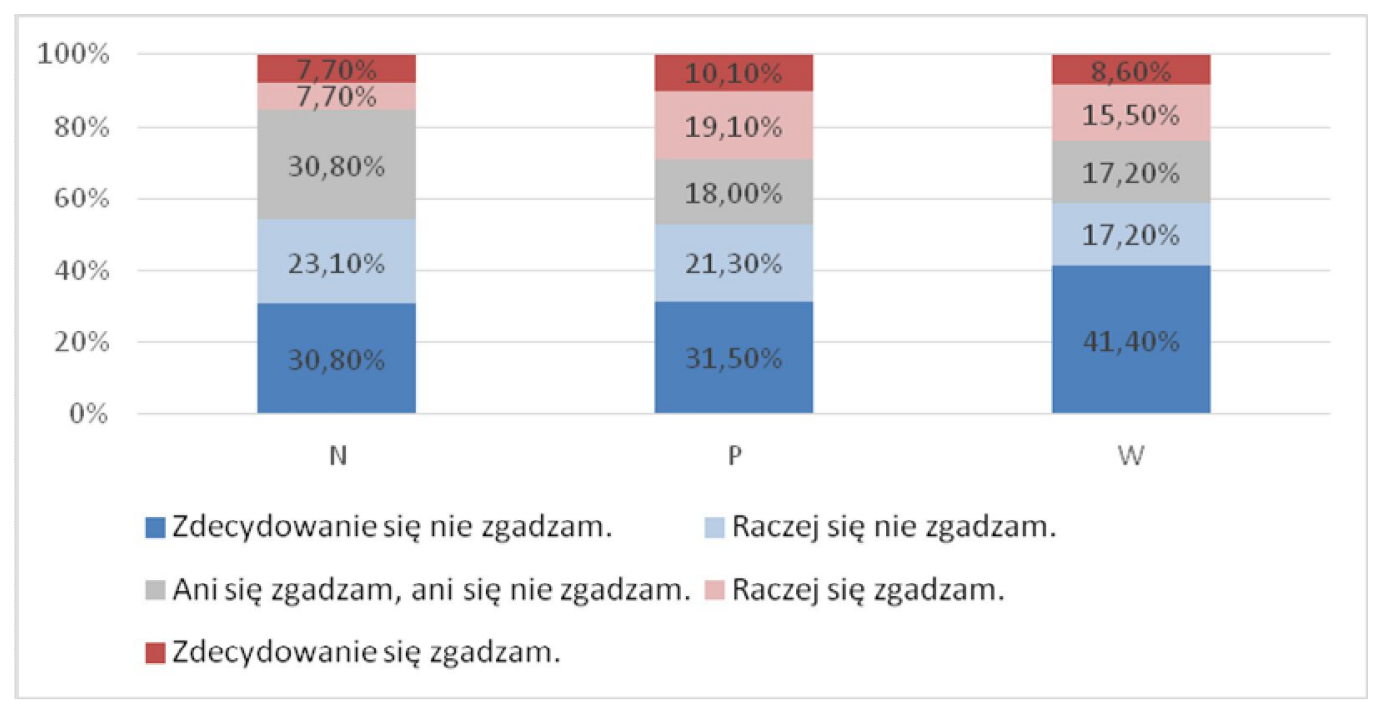

Źródło: wynik badań własnych

Wśród 62,1\% respondentów o wysokim poczuciu celowości nie zgadza się ze stwierdzeniem, że jest zwolennikiem aborcji. Podobnego zdania jest 52,8\% badanych o przeciętnym poczuciu celowości i $46,2 \%$ badanych o niskim poczuciu celowości. Zadeklarowanymi zwolennikami zabiegu przerywania ciąży jest 20,8\% osób o wysokim poziomie postaw, 30,3\% respondentów o przeciętnym poczuciu celowości oraz $23,1 \%$ osób o niskim poziomie. Osoby o niskim poziomie celowości najczęściej nie mają precyzowanego zdania $(30,8 \%)$.

\section{Rycina 7. Poczucie celowości a stosunek do zabiegu przerywania ciąży}

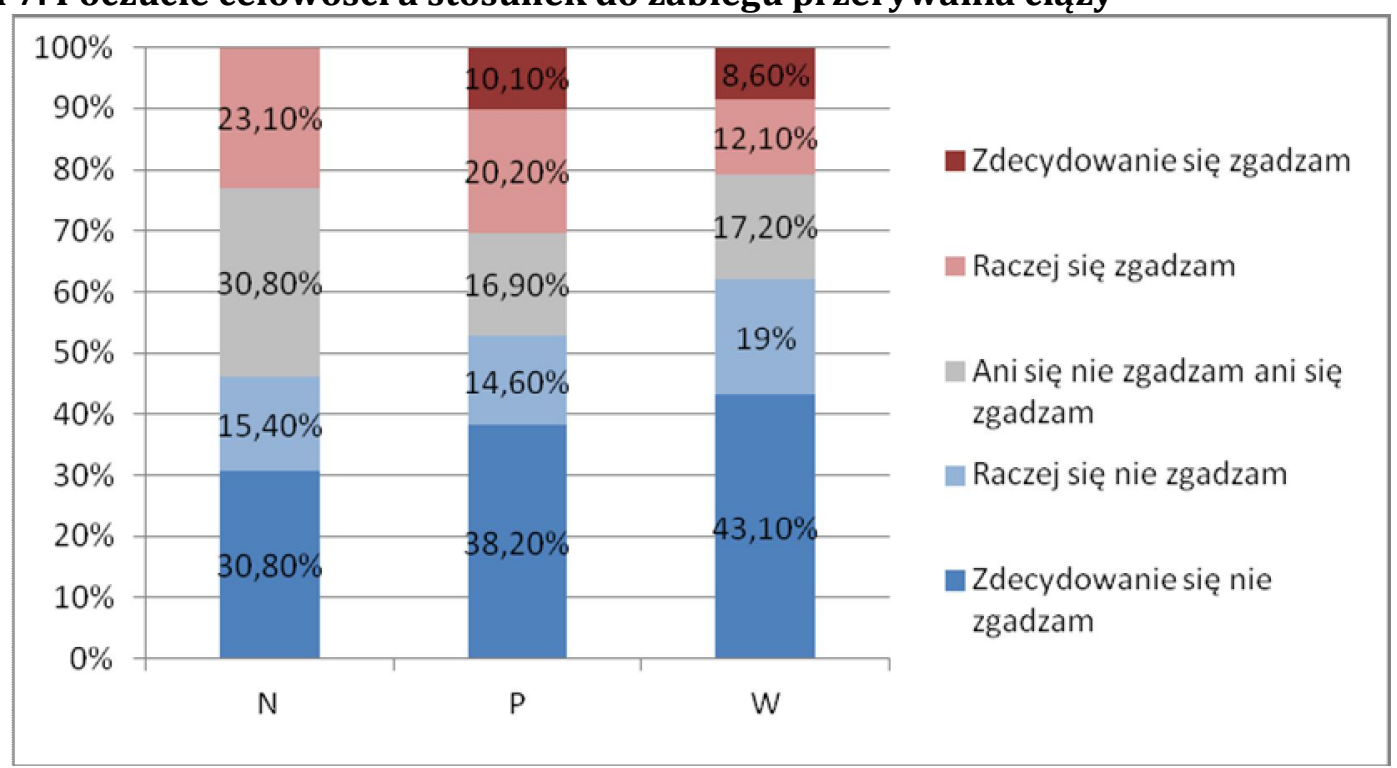

Źródło: wynik badań własnych

\section{Dyskusja}

Podstawowymi pytaniami, które nieodłącznie wiążą się ze świadomą egzystencją człowieka, są pytania dotyczące sensu i znaczenia daru ludzkiego życia. Na przestrzeni wieków zajmowano 
wobec powyższego problemu odmienne stanowiska. Jedne były radykalnie zorientowane na ochronę istnienia jednostki. Inne dopuszczały hierarchizację wartości życia osób różnych stanów, ras, narodowości i posiadanych przekonań, wykorzystując je jako nadane człowiekowi prawo decydowania o egzystencji innych osób. Na tle tak różnych przekonań i zachowań, wyłonił się problem zróżnicowanego stosunku do dziecka nienarodzonego.

Dzisiejsza kultura społeczeństw niekiedy próbuje powyższe zagadnienie marginalizować. Wpisuje się je w szereg tendencji światopoglądowych, które charakteryzują się dużą dozą subiektywizmu. Subiektywne rozumowanie tego zagadnienia dotyczy przede wszystkim oceny realnego zagrożenia dla ochrony ludzkiego życia od momentu połączenia żeńskiej komórki jajowej z męskim plemnikiem, aż do naturalnej śmierci, w tym również włączeniem możliwości dokonania aborcji do katalogu podstawowych praw i wolności człowieka.

Aborcja to bardzo gorący i kontrowersyjny temat, który wywołuje burzliwe dyskusje a ich wynik nie daje możliwości pogodzenia jej zwolenników i przeciwników. Aborcja jest istotnym tematem ponieważ $\mathrm{z}$ punktu widzenia rozwoju duchowego, życie ludzkie jest traktowane jako najwyższe dobro. $\mathrm{W}$ obowiązujących naukach moralnych występuje zasada: „nie zabijaj”. Pozbawienie możliwości do życia drugiego człowieka jest uważane za największą z możliwych zbrodni. Do walki pomiędzy zwolennikami i przeciwnikami aborcji dochodzi najczęściej na tle religijnym [16]. Religia jest jednym z najważniejszych zjawisk społecznych, tak jak język tworzy ona wzorce kultury i daje człowiekowi możliwość odrębności, ale ponad wszystko określa stosunek człowieka do wyznawanych $\mathrm{w}$ jej imię świętości. Trzema nieodłącznymi elementami religii uznano: wierzenia odnoszące się do celu istnienia świata i człowieka, kult związany z praktykami i obrzędami religijnymi a także instytucje, które wpływają na ukształtowanie formy życia ludzkiego i świadomość wyznawców religii [17]. Zgodnie z obowiązującymi zasadami moralnymi oraz etycznymi chrześcijaństwa zapisanymi w Piśmie Świętym, Bóg jest jedynym dawcą życia. Tylko on może je dać i tylko on może je zakończyć. Inne postawy, nawet najbardziej słuszne z punktu widzenia człowieka nie uzyskają przyzwolenia. Odpowiedzialnością za zabieg aborcji Kościół Katolicki obarcza zarówno kobietę, jak i mężczyznę lecz w świetle zasad katolicyzmu odpowiedzialności nie unikną również wszyscy, którzy chociażby w najmniejszym stopniu przyczynili się do zaistniałego faktu przerwania ciąży. Każda z tych osób, która dokonała współudziału w przestępstwie jest obciążona karą ekskomuniki. Jest to najwyższa i zarazem najcięższa w hierarchii kościoła kara i stanowi ona o wykluczeniu ze wspólnoty kościelnej, a także zakazie uczestniczenia w sakramentach świętych i całym życiu kościelnym [18].

W twierdzeniach dotyczących poczęcia człowieka stanowisko kościoła prawosławnego jest zgodne, ze stanowiskiem kościoła katolickiego. Obie religie uznają za początek istnienia ludzkiego jego poczęcie [19]. Judaizm podkreśla fakt, że życie jest najważniejsze lecz z dużym rozsądkiem wskazuje na okoliczność, że w przypadku wyboru między życiem płodu, a kobiety, to drugie uważa się za w pełni utworzone i podlegające ochronie [19]. Bezwarunkowa ochrona życia ludzkiego jest jedną z ważniejszych zasad napisanych w Koranie. Zgodnie z nią zabiegu przerwania ciąży nie wolno wykonać w momencie, gdy płód zostaje obdarzony duszą, czyli po około 120 dniach od chwili zapłodnienia. W islamie aborcja jest dopuszczalna tylko wtedy, gdy ciąża zagraża zdrowiu lub życiu kobiety ciężarnej [20].Zabieg przerwania ciąży w buddyzmie jest absolutnie zabroniony i traktowany jako przestępstwo. Może być wykonany tylko w momencie absolutnego zagrożenia dla życia kobiety ciężarnej. Zabicie istniejącego płodu jest uważane za zniszczenie potencjału Buddy [21]. 
Ochrona istnienia dzieci poczętych, a tym samym ich matek zajmuje szczególne miejsce w światopoglądzie i budowanych na jego podstawie postawach życiowych osób związanych zawodowo z ochroną ludzkiego zdrowia i życia.

Dyskutując o zabiegu aborcji, warto zastanowić się nad czynnikami wywołującymi decyzję o dokonaniu przerwania ciąży. Wśród występujących zmiennych poprzedzających decyzję o usunięciu płodu wymieniane są czynniki społeczne jak i psychologiczne. Wyjątkowa uwaga skierowana jest na osobowość kobiety, wyznawane wartości, pozycję życiową oraz wyznaczone cele życiowe. Zauważa się zależności między usuwaniem ciąży, a trwającymi problemami psychologicznymi, które występują w związku z doświadczeniem przemocy cielesnej w wieku dojrzewania oraz zaniedbania ze strony rodziny.

Niezmiernie istotną okazuje się dostępność wsparcia społeczeństwa, w tym realne wsparcie ze strony partnera, a także równowaga. Z przeprowadzonych badań wynika, iż większość aborcji dokonują kobiety, które są stanu wolnego, 52\% dotyczy pierwszych ciąż, natomiast $60 \%$ kobiet nie przekroczyło 25 roku życia. Czynnikiem, który istotnie wpływa na przerwanie ciąży jest wsparcie lub jego brak ze strony partnera. Największy wskaźnik przerwania ciąży zauważa się w sytuacji, gdy partner był nieobecny i nie wspierał kobiety w trudnych dla niej chwilach. Aborcja jest decyzją egzystencjalną, ponieważ dotyczy nie tylko kobiety, ale również jej dziecka i podejmowana jest w wyjątkowej sytuacji psychofizycznej, jaką jest sama ciąża. Stąd też dla zrozumienia uwarunkowań psychologicznych i konsekwencji przerwania ciąży uzasadnione jest zwrócenie uwagi na sytuację w której jest ona dokonywana [22].

Przerwanie ciąży nie jest obojętne, wpływa zarówno na sferę psychiczną, jak i fizyczną kobiety. Aborcja powoduje długotrwałe zaburzenia emocjonalne, które zwykle ujawniają się po długim okresie od wykonania zabiegu. Wśród następstw wpływających ujemnie na psychikę kobiety można wyróżnić: niepokój, osamotnienie, poczucie winy oraz krzywdy, trudności w nawiązywaniu nowych relacji społecznych, zaburzenia seksualne, a także zaburzenia psychosomatyczne. Pomimo wielu uwarunkowań natury religijnej, społecznej i etycznej kobiety postanawiają dokonać usunięcia płodu z przyczyn, które dopuszcza polskie prawo. Ciąża jest usuwana, gdy istnieje zagrożenie zdrowia lub życia matki, gdy po przeprowadzonych badaniach prenatalnych stwierdza się ciężkie wady u dziecka oraz gdy do poczęcia doszło $\mathrm{w}$ wyniku wykroczenia jakim jest gwałt lub stosunek kazirodczy.

\section{Wnioski}

1. Istnieje rozbieżność pomiędzy deklarowanym światopoglądem a zachowaniem w zakresie dopuszczalności przerywania ciąży w różnych sytuacjach.

2. Deklarowane poparcie dla aborcji w znacznym stopniu uzależnione jest od konkretnej, opisywanej sytuacji.

3. Religia pełni istotną funkcję jako wyznacznik praw moralnych i społecznych i przekłada się na deklarowane poglądy na temat problemów bioetycznych.

4. Należy podjąć działania mające na celu uświadamianie młodych mężczyzn konsekwencji i skutków aborcji dla kobiety poprzez kampanie społeczne.

5. W kontynuacji badań warto uwzględnić szerszy zakres postaw życiowych niż tylko poczucie celowości.

\section{Zalecenia dla praktyki pielęgniarskiej}

Istnieje konieczność zwrócenia szczególnej uwagi na zagadnienia bioetyczne w kształceniu studentów pielęgniarstwa. 


\section{Bibliografia/Bibliography:}

1. Sterkowicz S. Twarde prawo ale martwe. Problemy aborcji, antykoncepcji i demografii w Polsce. Gabinet prywatny 2007; 1; 158: 64- 69.

2. Zielińska E. Przerwanie ciąży warunki legalności w Polsce i na świecie. Warszawa 1990:39.

3. Muszala A., Strowieyski M., Ślipko T. Aborcja spojrzenie filozoficzne, teologiczne, historyczne i prawne. Wyd. Petrus. Kraków 2010:9-13.

4. Kluk P. Przyszło do swojej własności, a swoi Go nie przyjęli - czy aborcja powinna być dozwolona? Położna Nauka i Praktyka 2009; 4;8: 52-55.

5. Ustawa z dnia 27 kwietnia 1956r. o warunkach dopuszczalności przerywania ciąży (Dz. U. z 1956r., Nr 12, poz.61).

6. Ustawa z dnia 7 stycznia 1993r. o planowaniu rodziny, ochronie płodu ludzkiego i warunkach dopuszczalności przerywania ciąży (Dz. U. z 1993r., Nr 17, poz. 78).

7. Nesterowicz M. Prawo Medyczne. Wyd. TNOiK, Toruń 2000: 156.

8. Kilińska - Pękacz A. Aborcja - na granicy legalności i nielegalności. Magazyn Pielęgniarki i Położnej 2012; 10: 33.

9. Muszala A. Encyklopedia bioetyki. Polskie Wydawnictwo Encyklopedyczne Polwen. Radom 2005: 17.

10. Patyjewicz L. Aborcja i środki wczesnoporonne z perspektywy lekarskiego sumienia, w: Między literaturą a medycyną część II, Łoch E., Wallner G. (red), Wydawnictwo Norbertinum, Lublin 2007, s. 188-189.

11. Chazan B. Somatyczne następstwa aborcji. W: Aborcja przyczyny, następstwa, terapia. Chazan B., Simon W.(red.). Wydawnictwo Wektory. Wrocław 2009: 75; 83.

12. Norman J., Me Kay Hart D. Ginekologia. Wyd. Urban \& Partner. Wrocław 2006: 346.

13. Puzewicz-Barska J., Tarasiewicz M. Metody dokonywania aborcji. Nasze ciała, nasze życie. Wyd. Fundacja Współpracy Kobiet NEWW-Polska 2004: 387-388.

14. http://wciazy.familie.pl/artykul/Aborcja-w-Polsce-statystyki,6132,1.html [21.01.2016].

15. Libera A. Wpływ aborcji na zdrowie psychiczne i fizyczne kobiety. W: Psychologia w położnictwie i ginekologii, Makara-Studzińska M. (red.). Wyd. Lekarskie PZWL. Warszawa 2009: 164-172. 
16. Zieliński W. P. P. Aborcja za czy przeciw? Przewodnik duchowy - ciało, umysł, duch. 2012; 3: 15-18

17. Tworuscha M., Tworuscha U. Religie świata. Wyd. Bellona. Warszawa 2010: 25-40.

18. Szczygieł K. W trosce o życie. Wybrane dokumenty Stolicy Apostolskiej. Wyd. Biblos. Tarnów 1998: 58.

19. Olszewska J., Czerwińska-Ospiak A., Michalik A., Kunat K. Spojrzenie na ciążę i poród przez pryzmat różnych religii. Problemy Pielęgniarstwa 2013; 21; 4: 534-541.

20. Bielawski J. Islam, religia państwa i prawa. Wyd. KAW. Warszawa 1973: 11-13.

21. Donden J. Sztuka trwania w harmonii i zdrowiu. Wprowadzenie w medycynę tybetańską. Wyd. EM. Warszawa 1992: 16-17

22. Kulpa A. Psychologiczne konsekwencje aborcji. Pielęgniarka i Położna 2005; 11-12: 8-9. 